\title{
Pollen and spore events from the marine Tertiary of North Europe
}

\author{
M. C. BOULTER \\ Palynology Research Unit, North East London Polytechnic, Romford Road, London E15 4LZ
}

\begin{abstract}
Results are presented of semi-quantitative palynological analyses from two cored boreholes. One is from the central North Sea (16/1-1) and penetrates sediments from the Middle Miocene to the Palaeocene. The other is from the Voring Plateau of the Norwegian Sea (D.S.D.P. Leg 38 site 338) and penetrates sediments from the Early Miocene to the Early Eocene. The results show a number of interesting palynological features and these are discussed in relation to other evidence. The most important of these are: 1 , the small range of angiosperm pollen in the Palaeocene; 2 , changes in the dinocyst:pollen ratio in Early Eocene sediments in both cores at about the time of an increase in Subtriporopollenites pollen; 3 , the presence of triprojectate pollen in the Late Eocene and Middle Oligocene sediments of site 338 some of which may not be reworked; and 4 , a clear difference between Neogene and Palaeogene pollen taxa.
\end{abstract}

\section{INTRODUCTION}

It is well known that in Tertiary marine sediments, pollen and spores have much less biostratigraphic value than dinocysts. One example of this discrepancy can be seen from the International Geological Correlation Programme (I.G.C.P.) Project 124 Progress Report 6 (Vinken \& Meyer, 1980) which gives a preliminary summary of the findings of workers in the two divisions of palynology, pollen and dinocysts, in the "North West European Tertiary Basin". The reasons for this different biostratigraphic value are debatable, though transport and evolutionary processes can be expected to play a part. This is because different controlling mechanisms apply to both the transport and evolution of pollen and cysts, and there are also different attitudes to taxonomy by the microscopists from the two schools of palynology. In the marine realm, pollen and spores have been transported in various ways from their original site of growth, whereas cysts from the marine algae of the Dinophyceae are deposited solely by marine influences. This is one reason why dinocysts are more useful than pollen for marine biostratigraphy. Another is that dinocyst taxonomy is less cluttered with nomenclatural complexity. This relative simplicity, however, may yet change as our knowledge of dinocysts increases; dinocyst taxonomy may soon begin to suffer from "ballooning" in the same way as that of so many pollen and spores over the last 30 years, with the consequent effect on ranges and zonations.

Those studying Tertiary palynology in Europe have rarely had the opportunity to undertake examination of really long sections, whether in marine, deltaic or terrestrial deposits. Collinson et al. (1981) have reported briefly on what must be one of the longest sections studied publicly, extending through most of the Eocene in nearshore deposits in the Hampshire
Basin, and Meyer (pers. comm.) has results from a long deltaic sequence in the Wursterheide borehole through the Neogene of N.W. Germany. In the deeper marine deposits, the only published work describing whole assemblages from long sections through the Tertiary is from the Deep Sea Drilling Project. The most important contributions by palynologists are from Leg 38 (Koreneva et al., 1976 - pollen and spores; Manum, 1976 - dinocysts) which extends from the Early Eocene to the Pleistocene in the Norwegian Sea, and from Leg 48 (Costa \& Downie, 1979 - dinocysts) which extends from the Eocene to the Pliocene in the Rockall Basin. This present account adds to that work by presenting new data from two long sections through the marine Tertiary of N.W. Europe: from the cores of North Sea well 16/1-1 and of D.S.D.P. Leg 38 hole 338 at the Voring Plateau in the Norwegian Sea.

\section{PRESENTATION OF NEW RESULTS}

Fig. 1 shows the semi-quantitative occurrence of pollen and spore taxa from Esso well 16/1-1 in the central part of the North Sea, drilled in 1978. The section extends from the Palaeocene to the Middle Miocene through about $1,750 \mathrm{~m}$ of sediments. The stratigraphic divisions recorded against the depths in Fig. 1 are taken from the log that is available from the Norwegian Petroleum Directorate.

The entire section is dominated by the occurrence of Inaperturopollenites and Pityosporites, though there are parts where counts of these two genera are low due to an increase in the proportion of dinocysts in the assemblages. Other genera rarely account for more than $5 \%$ of the pollen and spore sum. Some of these taxa occur throughout the Eocene, Oligocene and Miocene parts of the section, and their names are listed 
in the legend to Fig. 1. The palynological study of this section 16/1-1 does show a number of interesting features, which may reflect both biostratigraphic and palaeoenvironmental features. In the six Palaeocene samples, Platycaryapollenites and Abiespollenites are the only pollen present with the long ranging inaperturates and bisaccates. The Eocene parts of the section contain small numbers of pollen from taxa that are usually associated with terrestrial sediments from the N.W. European Eocene: Arecipites, Plicapollis, Pompeckjoidaepollenites, Trudopollis and Erdtmanipollis. A particularly interesting feature of the Early Eocene part of the section, at a depth in the core of about
$1,250 \mathrm{~m}$, is the dramatic change in the proportion of pollen and spores to dinocysts (the ratio curve of the two forms is shown in Fig. 1) at about the same time that there is a unique increase in the occurrence of Subtriporopollenites. The palaeoecological interpretation of these changes will be discussed below.

Other stratigraphically significant pollen are found in the Oligocene and Miocene parts of the section, particularly Graminidites, Cedripites, Tsugaepollenites (a Miocene form), Cycadopites, Corsinipollenites and a Miocene form-species of Erecipites. Fig. 2 shows the semi-quantitative occurrence of pollen and spore taxa from D.S.D.P. Leg 38 hole 338, through more than
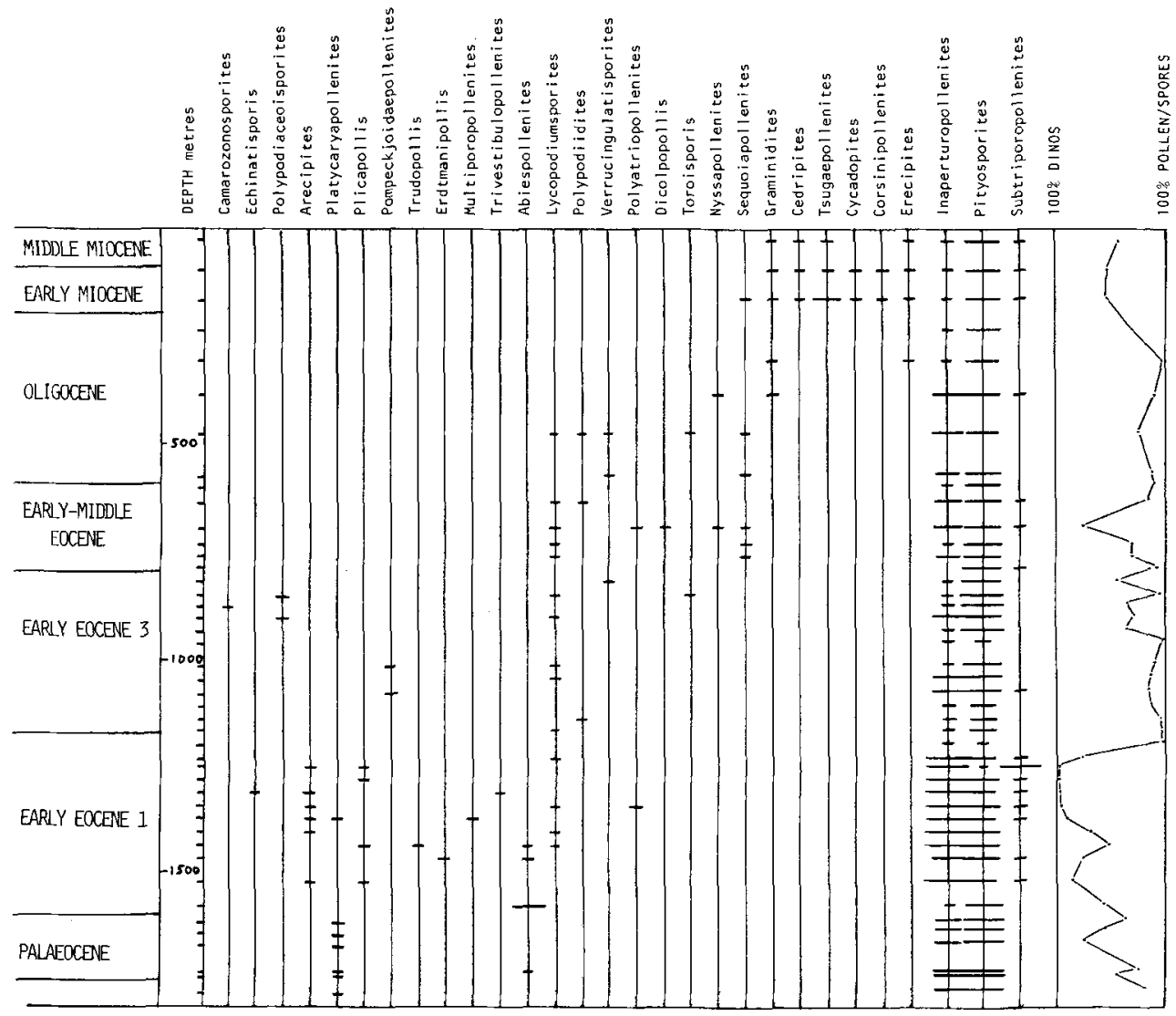

Fig. 1. Semi-quantitative pollen diagram of North Sea well 16/1-1. The shorter bars represent palynomorph occurrences at less than 5\% frequency; the longer bars greater than $5 \%$.

Additionally, the following taxa range more or less continuously throughout the section and are never present with more than 5\% frequency: Polypodiaceaesporites, Baculatisporites, Cicatricosisporites, Deltoidospora, Osmundacidites, Stereisporites, Trilites, Triplanosporites, Sciadopityspollenites, Monocolpopollenites, Salixipollenites, Tricolpopollenites, Tricolporopollenites, Engelhardtioipollenites, Momipites, Myricipites, Tiliaepollenites, Polyvestibulopollenites. 
$400 \mathrm{~m}$ of the Tertiary (Early Eocene - Pleistocene) at the Voring Plateau in the Norwegian Sea. The stratigraphic divisions and other data for this section are contained in the Initial Report of Leg 38 (Talwani et al., 1975).

Although the details of the assemblage are different to those of well 16/1-1, there are many common features. Biostratigraphically, Platycaryapollenites occurs most abundantly in the Palaeocene, Arecipites and Plicapollis occur in the Eocene, and also here there are other taxa familiar in European Lower Tertiary terrestrial deposits, such as Goczanisporis, Gothanipollis, Pistillipollenites and Ulmipollenites. An important constituent of the assemblage in nine of the Late Eocene to Middle Oligocene samples is about 35 specimens of triprojectate pollen. A representative selection of these specimens is shown in Pl. 1. Most of these pollen resemble Late Cretaceous forms (Srivastava, 1970) and may have been reworked from sediments of this age. Other similar specimens have been found in another core from Leg 38, hole 346, drilled at the western side of the Voring Plateau, where the source of the sediments is from the Greenland direction rather than the Norwegian (as is the case in hole 338). This confirms that the parent plants of this triprojectate pollen had a very broad distribution in the Late Cretaceous (Srivastava, 1983). However, some of the better preserved specimens of triprojectate pollen ( $\mathrm{Pl}$. 1, figs. 10-12) are smaller than the reworked Cretaceous forms and show closer similarity with recently described Oligocene forms than with these betterknown Late Cretaceous ones. The Norwegian Sea Leg 38 specimens have an equatorial diameter of $15 \mu \mathrm{m}$, the polar axis is $30 \mu \mathrm{m}$ and the three equatorial projections are about $8 \mu \mathrm{m}$ long. In the best preserved specimens, it is clear that the exine has a microreticulate surface sculpture. At least seven such specimens have been identified from the Middle Oligocene and Late Eocene parts of hole 338 (Fig. 2). These specimens appear to be similar to those described as Parviprojectus by Staplin (1976) and by Rouse (1977) and others from Middle Eocene - Oligocene deposits of the Canadian Arctic (Norris, 1986). Triprojectate pollen have been described from Oligocene deposits before. One of the earliest records is from Alaska (Wahrhaftig et al., 1969 ), and others are from the Bohai region of China (Zhou et al., 1978) and the western Siberian plain (Filippova, 1957). There is a brief record from the Neogene of the island of Sakhalin, in the Sea of Okhotsk 1,000km north of Japan, (Brutman, 1973); the abstract gives no way of checking if this is reworked.

Of course, there is a possibility that all these triprojectates from holes $346 \& 338$ are reworked from older sediments. Arguments against this view are that: 1, some of the Leg 38 specimens do resemble the smaller triprojectates described from Palaeogene sedi- ments, 2, they occur in the Norwegian Sea sediments from both east and west of the Voring Plateau, 3, there is no evidence of other Late Cretaceous or Palaeocene taxa having been reworked in these deposits, 4, many of the specimens are well preserved and of the same colour as other pollen. If the specimens are from Palaeogene plants, their presence has implications in the debate about the age of the interbasaltic sediments of Mull and elsewhere (Srivastava, 1975).

Some of the samples from D.S.D.P. Leg 38 holes 338 and 346 have also formed the basis of a palynodebris study, as a control for the recently published study of dispersed plant parts in the mudstones and sands of the North Sea Forties Field Palaeogene deposits (Boulter \& Riddick, 1986). The semi-quantitative counts of palynodebris from Leg 38 are based on this recent classification of dispersed plant parts and are presented in Fig. 3. The conclusions from the D.S.D.P. material are consistent with those from the Forties Field work: the remains of well preserved wood (comprising rays, tracheids and degraded bundles) are mainly restricted to shallow water sedimentation.

The palaeoecological significance of the results from D.S.D.P. hole 338 has much in common with what has been intepreted from the results of the core 16/1-1. In both sections the dinocyst:pollen and spore ratio makes an abrupt change at about the time of a high occurrence of Subtriporopollenites in the Early Eocene. It appears from this work that the same physical events have been traced by the palynology of the sediments in the Norwegian Sea and the central part of the North Sea, more than $1,000 \mathrm{~km}$ to the south.

\section{CRETACEOUS BACKGROUND}

These results from the Tertiary of hole $16 / 1-1$ and D.S.D.P. Leg 38 show three particularly interesting features:

1. The presence in the Palaeogene of a small form of triprojectate pollen, which may or may not have been reworked from the Cretaceous.

2. A very limited assemblage of no more than four form-genera in the Palaeocene samples of well $16 / 1-1$.

3. A big difference to the assemblages described from uppermost Cretaceous sediments.

So it is useful to consider the pertinent fossil record from the Late Cretaceous sediments in the North Europe region. This gives useful indications about the evolution and migration of plants there over the time of the Cretaceous/Tertiary boundary, as shown by the pollen, particularly the triprojectates, the triporates and the tricolpates.

Much has been written recently (see Rev. Palaeobot. Palynol., 35, parts 2-4, 1981) about the so-called Aquilapollenites and normapolles Provinces, based on evidence from presence and absence records from short 


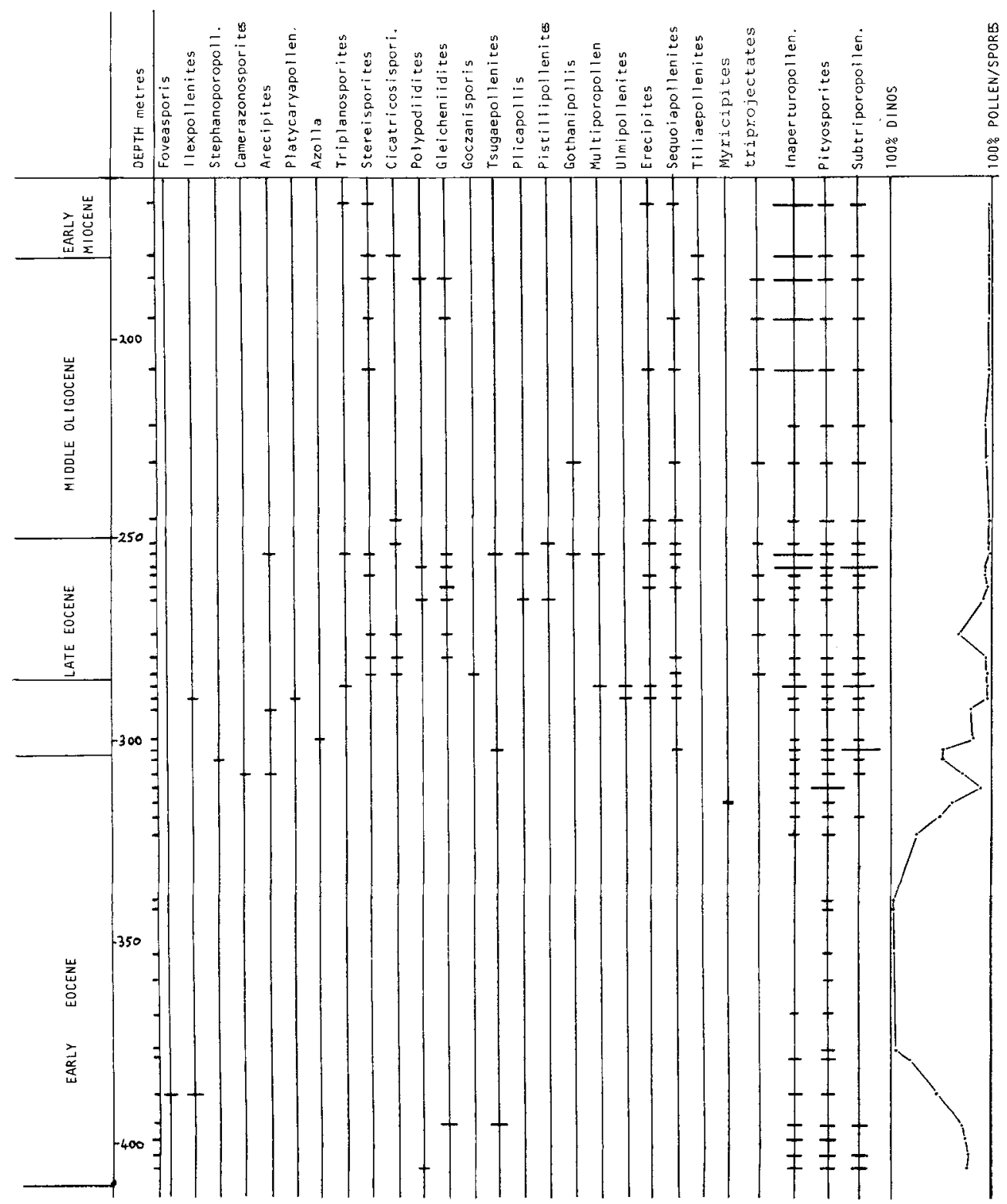

Fig. 2. Semi-quantitative pollen diagram of Norwegian Sea D.S.D.P. Leg 38 site 338. The shorter bars represent palynomorph occurrences at less than $5 \%$ frequency: the longer bars greater than $5 \%$.

Additionally, the following taxa range more or less continuously throughout the section and are never present with more than 5\% frequency: Deltoidospora, Osmundacidites, Baculatisporites, Polypodiaceaesporites, Lycopodiumsporites, Cycadopites, Sciadopityspollenites, Monocolpopollenites, Nyssapollenites, Trivestibulopollenites, Engelhardtioipollenites, Momipites, Tricolpopollenites, Tricolporopollenites, Salixipollenites, Periporollenites, Polyvestibulopollenites, Polyatriopollenites.

sections and surface samples within the northern hemisphere (Batten, 1984). The lack of published counts of at least 200 specimens from each sample make interpretations of these records difficult to compare with Tertiary palynological information, but there is the clear, though subjective, inference that the Aquilapollenites and especially the Normapollis types have the most stratigraphical and botanical interest to Mesozoic palynologists with interests in angiosperm palaeobotany. These two groups of angiosperms are 
those which do seem to have survived the Cretaceous/ Tertiary transition. For other angiosperms, the fossil pollen evidence is much less informative and in North Europe none appear commonly below and above the boundary.
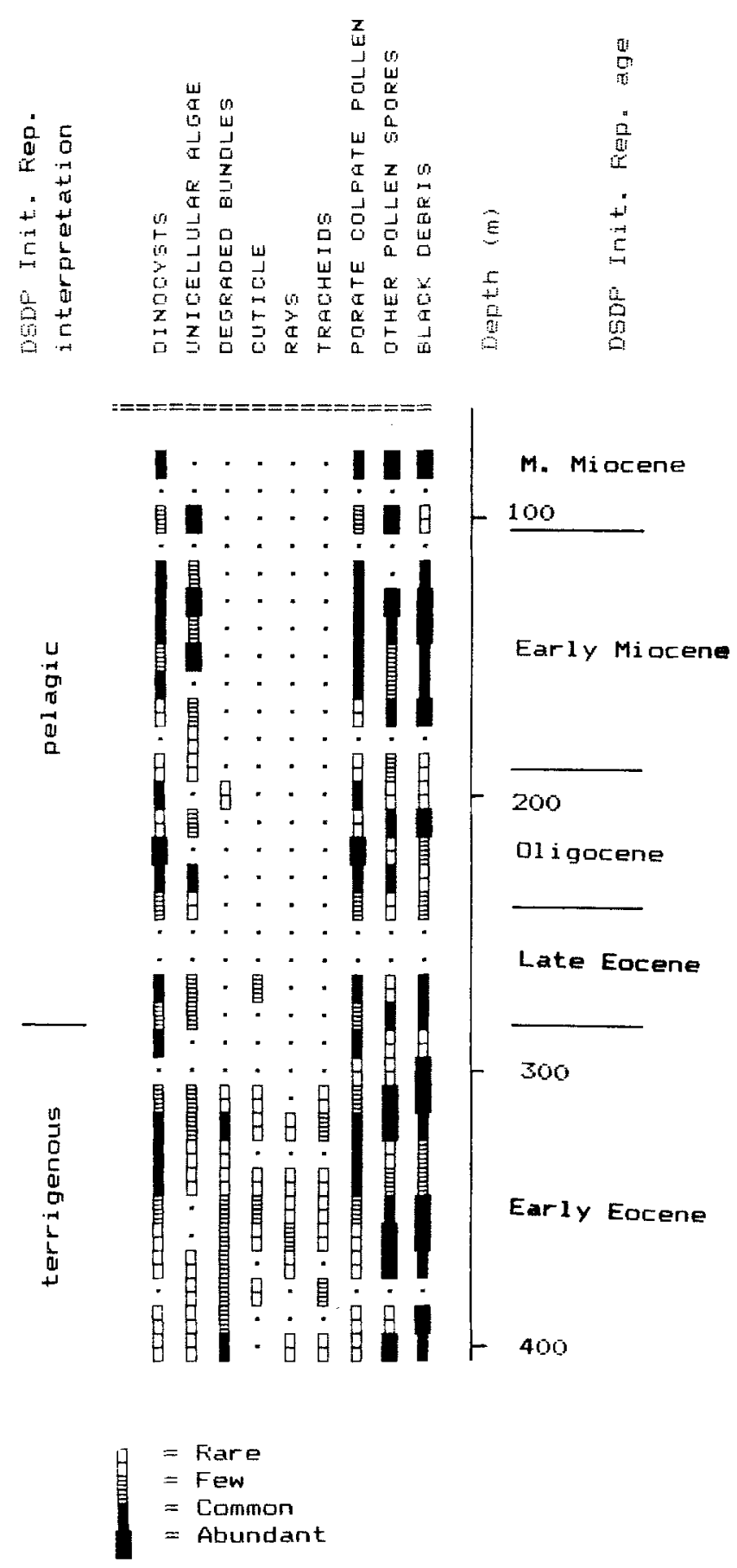

Fig. 3. Semi-quantitative palynodebris counts from D.S.D.P. Leg 38, site 338.
The most comprehensive and detailed studies of Maastrichtian pollen are by Srivastava from the Edmonton Formation of Canada (Srivastava, 1970) and elsewhere. There, and in others of his publications (referenced in Srivastava, 1981), he shows that several taxa of these other dicotyledonous pollen are present in the Cretaceous, and he often gives semi-quantitative details. In addition to normapolles and triprojectate dicotyledonous pollen the Edmonton Formation is shown to have colpate, colporate and porate pollen, many of which bear form-generic names commonly used in the Tertiary, for example, Myricipites, Faguspollenites, Quercoidites, Ilexpollenites, Caryapollenites, Nyssapollenites and Proteacidites. Of course, these names do not necessarily mean that these fossils are from plants closely related to Tertiary ones.

The same limits apply to the palynological data from the Eureka Sound Formation in the Canadian high Arctic (Hickey et al., 1983). Although only part of the assemblage is listed in their article, many of the taxa mentioned are of porate pollen with names familiar to European Tertiary palynologists. For other reasons, Norris \& Miall (1984) have challenged the 1983 dating of the Cretaceous part of this section, thus supporting the view that many plants yielding triporate pollen did not evolve until after the K-T boundary.

Though it is not clear from the published data, the implication from all this work is that colpate and porate pollen familiar to the Tertiary palynologist is very rare in the Late Cretaceous. This observation is shown clearly by Frederiksen \& Christopher's (1978) text-fig. 1 giving relative frequences of triatriate pollen in a section from the Santonian to the Chattian in South Carolina.

By modern day trends, the most productive source of angiosperm (and aborescent) remains can be expected to be found in the tropics. Tropical sediments across the $\mathrm{K}-\mathrm{T}$ boundary have been described in unpublished thesis work by Salami (1983). But there is no clear change of the angiosperm pollen across the boundary, and tricolpates, tricolporates and some triporates (what Salami calls Trivestibulopollenites, Echitriporites and Proteacidites) are shown by his quantitative data to be present in larger quantities below the boundary. These deposits are well to the south of the Normapollis province, though it is interesting that both here and in Srivastava's (1970) Edmonton Formation, there is pollen thought to be from early Proteaceae-type angiosperms. Salami's 'work suggests more active angiosperm evolution in the tropics during the Late Cretaceous.

\section{EUROPEAN LOCALITIES NEAR THE CRETACEOUS/TERTIARY BOUNDARY}

Despite the opportunity presented by the D.S.D.P. 
over the last decade to recover pollen bearing sediments from the marine realm, palynology has been unable to contribute to the debate about events at this boundary due to the lack of well dated material. Onshore, however, Tschudy's work on sediments from Texas gives evidence of a "fern spike" at, or close to, the K-T boundary (Tschudy \& Tschudy, 1984). "Characteristic Palaeocene floras gradually developed from residual floras in these refugia" which persisted "after massive devastation of the terminal Cretaceous flora". Unfortunately, there is no published work on the palynology from sediments across the boundary in N.W. Europe. What does exist in this part of Europe is a small number of exposures which some say are Maastrichtian and others say may be Palaeocene. Despite the attempts to give objective dating of associated volcanic rocks by radiometric techniques, there is still little evidence from these deposits to assist those interested in reconstructing land vegetation at this time.

\section{Greenland}

Batten (1982) has illustrated very degraded triprojectate pollen from shales interbedded with rhyolites at Kap Washington in northern Greenland, dated radiometrically at $63 \pm 2 \mathrm{Ma}$. Bisaccates and spores are present, "but all other identifications are questionable" (Batten et al., 1981). Presently, this locality is less than $1,000 \mathrm{~km}$ from the Svalbard sections (see below). Earlier, Croxton (1980) reported four species of Aquilapollenites (s. l.) from the Maastrichtian Palaeocene (?) of the Nugssuaq peninsula, of central west Greenland.

\section{Svalbard}

This classic palynological study (Manum, 1962) described about 90 taxa of pollen and spores. The quantitative analyses show that spores, bisaccates, inaperturates, normapolles and triporates are the most common forms. Triprojectates are absent. Manum concluded from the pollen that the sediments are of a Palaeocene-Eocene age, and more recent studies of the dinoflagellate cysts suggest a Lower/Upper Palaeocene age for the Central Basin (Throndsen \& Manum, in press). Unfortunately no radiometric age determinations exist for the Spitzbergen Tertiary due to the lack of suitable lithologies.

\section{Faeroe Islands}

Lund (1983) has reported briefly on "the microflora from Rokhagi [which] comprises thirty-five species". Nine of these are mentioned and no reason is given why the pollen and spores indicate "a late Paleocene (Landenian) age": normapolles and triprojectates are not included in the species listed. "Radiometric datings (K/Ar) show an age from 49-62 million years", and the author concludes that "this microflora is younger than the Maastrichtian to Danian microflora known from interbasaltic coals of Mull, Scotland, and is older than the interbasaltic microflora from Iceland". No reasons are given in this short article.

\section{Northern North Sea}

Batten (1981) has reported briefly on cuttings and cores from wells drilled in this region and to the west of the Shetland Islands. The assemblages contain triprojectates and normapolles.

\section{Isle of Mull, Scotland}

Simpson (1961), Martin (1968) and Srivastava (1975) have each contributed to the palynological history of these complex interbasaltic deposits. The palaeobotanical history is complex too and this is not the place to summarise the details. The pollen and spores from here show a confusing assemblage and different conclusions have been made about their identity, age and palaeoecology. Much of the trouble may be due to the lack of well measured and well sampled sections. All three authors have recorded triprojectate pollen, and normapolles are known to be present as well. Radiometric dates from the earliest lavas approximate to 63-61Ma (Evans et al., 1973) whilst the latest may have been up to $8 \mathrm{Ma}$ afterwards (Curry et al., 1978, p. 36). All these deposits are difficult to ascribe with certainty either to the Maastrichtian or the Danian. Whatever their ages, the pollen and spore assemblages that have been described give little help to settle the question. In most cases, they have a very small and limited variety of useful angiosperm pollen, and none of the assemblages have been fully described by percentage frequency counts.

It is clear that the deposits close to the boundary are not dated objectively, and that (with the exception of the normapolles) the angiosperm pollen is usually rare or difficult to see in the light microscope. No sections in Europe are known to cross the boundary to yield long sequences of pollen-bearing sediment and few if any samples have been studied by electron microscopy as a routine to identify the specimens, and to provide accurate counts. What little we do know about angiosperm pollen occurrence in N.W. Europe at the K-T boundary suggests that:

1. Plants producing triprojectate and normapolles pollen were among the main angiosperms to continue.

2. Many small (less than about $20 \mu \mathrm{m}$ ) triporate and tricolp(or)ate pollen became extinct (or we may not know of them in the Palaeocene due to little sem work), although Platycaryapollenites-type pollen reach a peak in the Palaeocene.

3. Larger (more than about $25 \mu \mathrm{m}$ ) triporate and tricolp(or)ate pollen became abundant and many new taxa originated thereafter.

\section{THE EVIDENCE FROM THE NEW TERTIARY SECTIONS}

The lack of accurately dated sections with pollen- 
Tertiary pollen and spore events

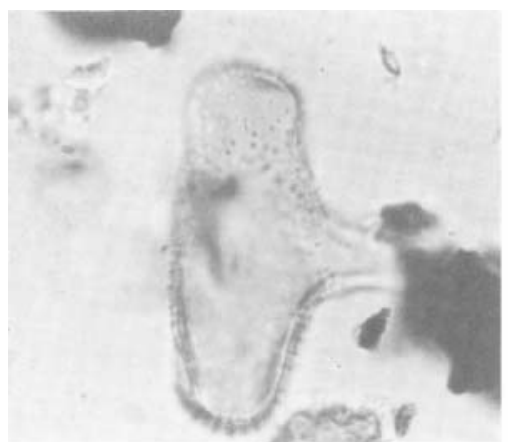

1

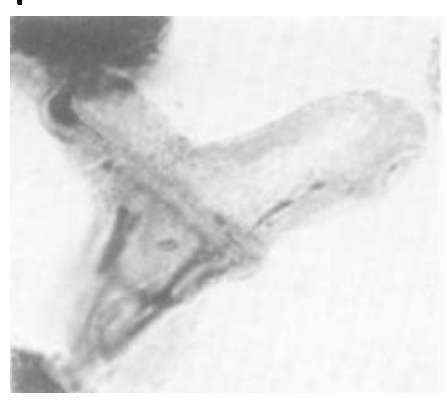

4

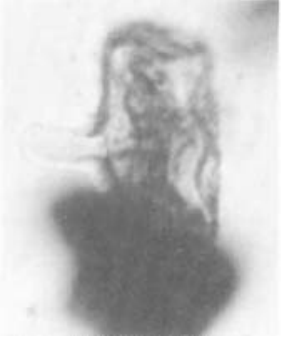

B

9

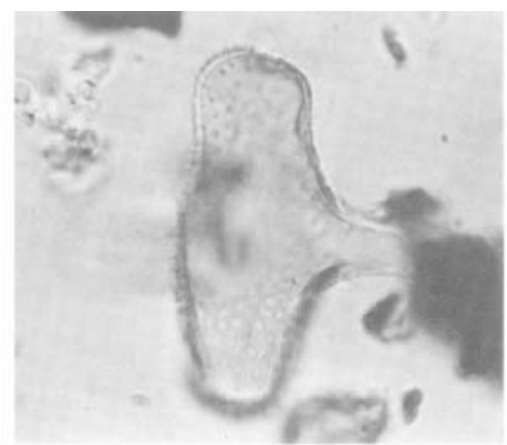

2
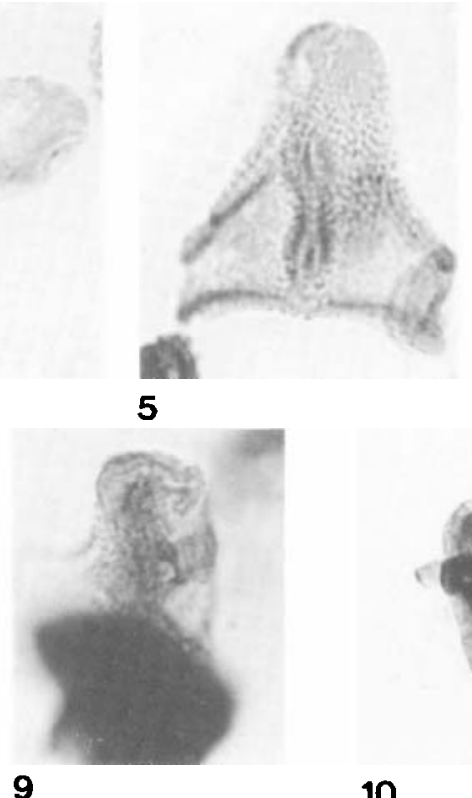

5

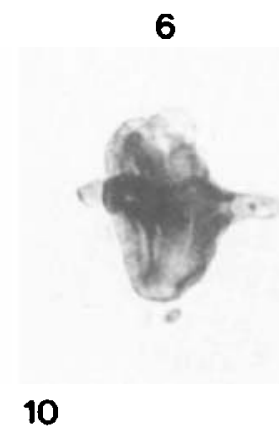

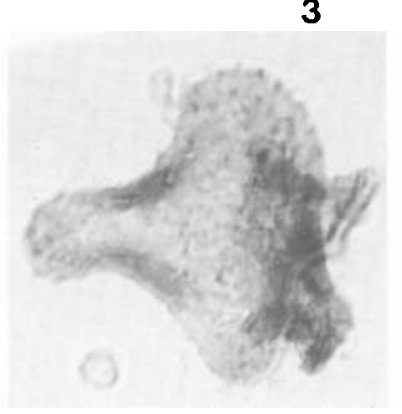

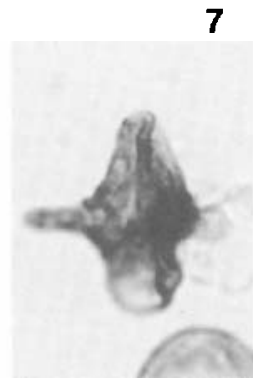

11

7

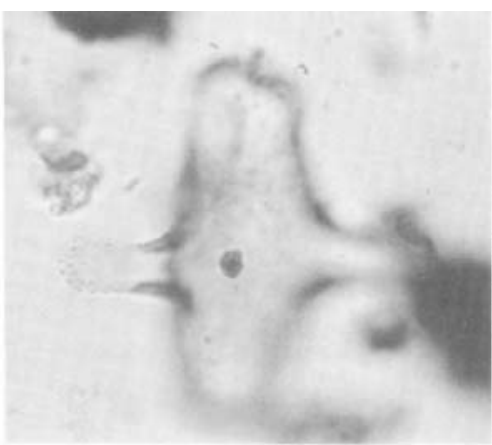

3
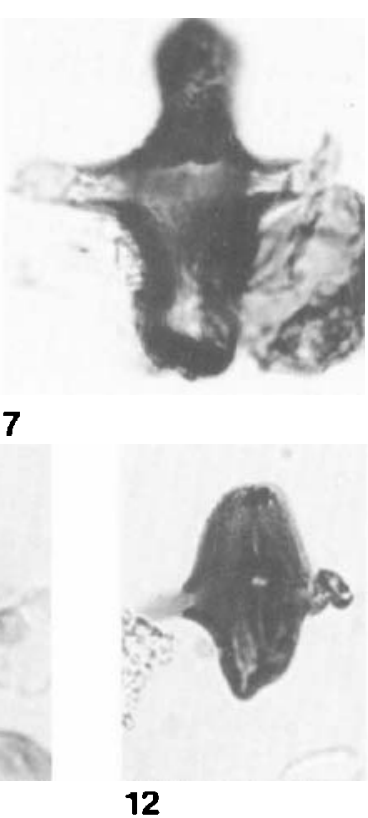

Explanation of Plate 1

Triprojectate pollen from site 338 of D.S.D.P. Leg 38

All figures are $\times 1,000$

Figs. 1-7. Late Cretaceous forms may be reworked.

Figs. 8-12. Smaller forms with similar features to triprojectate pollen described from Oligocene deposits elsewhere (see text); cf. Parviprojectus Rouse, 1977. 
bearing sediments from the Danian (Lower Palaeocene) of N.W. Europe make it impossible to give a clear picture of the immediate consequences of changes at the K-T boundary. The evidence presented here from the cored $16 / 1-1$ in the central part of the North Sea gives a limited view of land vegetation from pollen deposited in the marine realm. Just four taxa are present, Platycaryapollenites, Abiespollenites, Pityosporites and Inaperturopollenites. Pollen identified from the Palaeocene sediments of the Forties Field of the central North Sea (Boulter \& Riddick, 1986) show the same four taxa with four extra spore genera. Inaperturate and bisaccate pollen dominate all these sections. Not until the Late Palaeocene Thanetian deltaic deposits of northern Europe does a clear picture of the vegetation emerge from palynological evidence. This is shown most recently in the unpublished $\mathrm{PhD}$ thesis of Allen (1982) which confirms the general picture of earlier work on the European Palaeocene vegetation. Platycaryapollenites is a noticeably important pollen type in all these deposits, whether deltaic or truly marine.

The Eocene parts of cores $16 / 1-1$ and 338 contain occasional specimens of some of the stratigraphically significant taxa nominated by IGCP Project 124, as well as the rare specimens of triprojectates (hole 338 only) and normapolles, as has already been discussed. Because they are marine deposits their rare occurrence makes any precise zonation based on them quite impossible. The dinocyst:pollen and spore ratio is the one piece of evidence from this work that might be used for correlation together with the associated increase in Subtriporopollenites. The other pollen types present can give no more than general confirmation of the ages of each Series interval (Oligocene, Eocene or Palaeocene) present in the sections. Even this is perhaps surprising for marine sections thought to have been deposited some way from the vegetation sources.

The Late Eocene and Oligocene parts of the two cores also show some rare specimens of characteristic taxa, such as Gothanipollis and Dicolpopollis. There is no clear change in the pollen and spore assemblage in those parts of each section where the Late Oligocene discontinuity is expected to be. Although the likely consequence of an abrupt change in sea level might be expected to show up in the pollen and spores, the results from this part of each section suggest that land vegetation did not change appreciably then. Unfortunately, only five samples from Neogene sediments are included in the work presented here, not enough to give reliable information about the changes. Three of these samples are from well 16/1-1 and these do show the introduction of specimens of the Neogene forms of Cedripites, Tsugaepollenites, Cycadopites and Corsinipollenites. But there are not enough samples from these marine Neogene sediments to be useful to contribute to the events included in what Traverse (1982) calls the Ultimogene. Fig. 4 summarises the palynological events that are recorded in the two new sections presented here, and compares them to the three "palyno-events" identified by Manum (1976) from his cyst ratios at five sites in Leg 38. Unfortunately, geophysical and nannofossil data are not available for hole 16/1-1 and so precise stratigraphic comparison with hole 338 is not possible. Manum (1976) related his

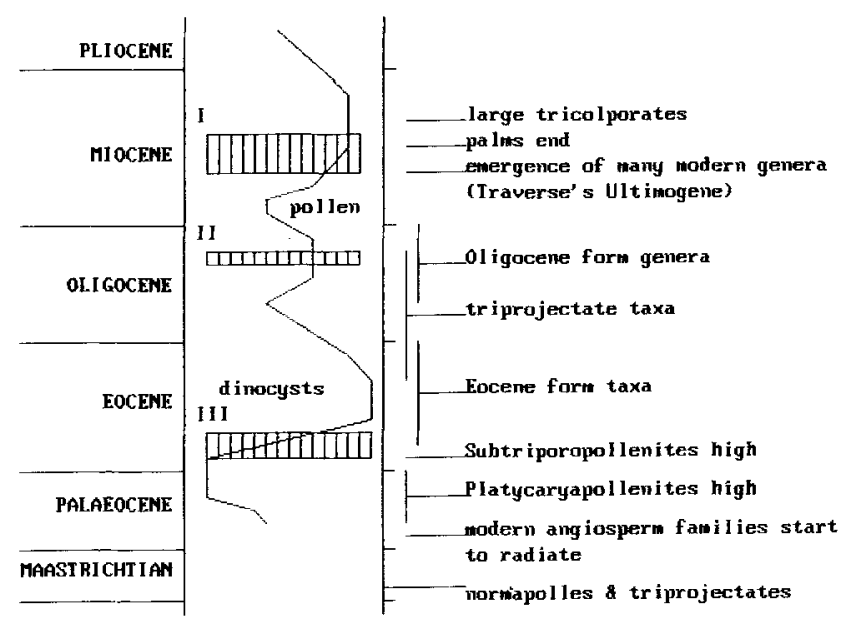

Fig. 4. Generalised summary of pollen and spore events in the marine Tertiary of North Europe. Intentionally, there is no stratigraphic scale. Events are based on data from the two cores described in this paper. Vertically lined boxes I-III approximate Manum's (1976) suggested "palyno-events". The dinocyst:pollen curve is based on non-absolute counts.

three palyno-events to the subsidence of the IcelandFaeroe Ridge (Early-Middle Miocene event), the opening of the Knipovich Ridge and the shift of the spreading axis (Oligocene event) and to the opening phase of the Norwegian Sea (Eocene event). These features are identified on the location maps of Fig. 5, and the interpretations equally fit the new data presented here. Related changes in palaeoclimate (Boulter, 1984; Traverse, 1982) and the evolution of land vascular plants have also contributed to the changes seen in the sections. The importance of plant migration in the Tertiary of northern Europe will be better understood when more long sections from the marine realm have been studied over a wider area. 

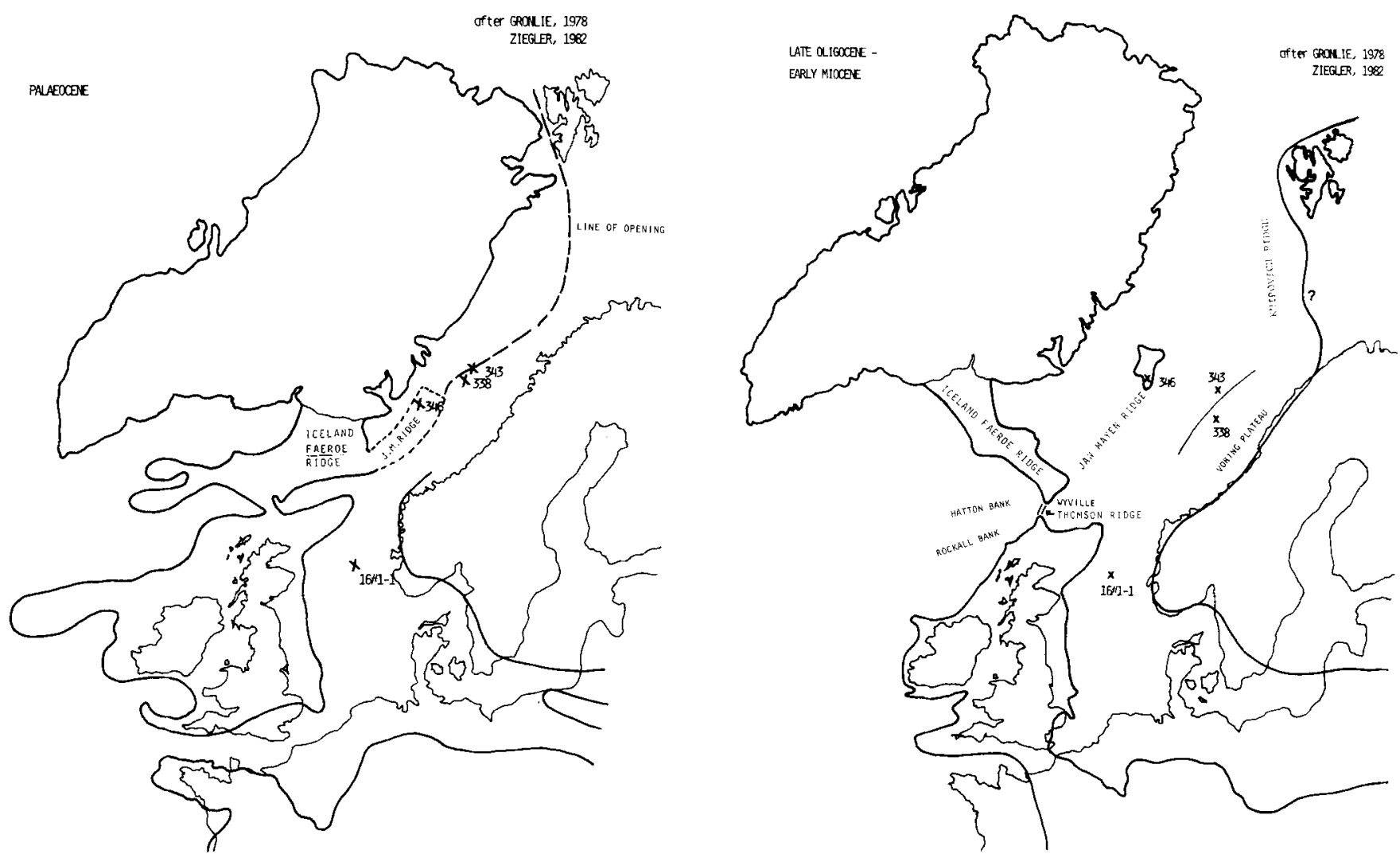

Fig. 5. Location of the two sections discussed in this paper at the Late Palaeocene and the Late Oligocene. Based on maps by Gronlie (1978) and Ziegler (1982).

\section{ACKNOWLEDGEMENTS}

The author would like to thank Dr. Y. Caro, Prof. S. B. Manum and Dr. V. Wiggins for material and helpful discussions, his research assistant D. L. Craig for many hours work at the microscope, and Dr. B. Tiffney and Dr. N. F. Hughes for critical readings of the first draft manuscript. Statoil, Norway financed some of the later stages of this work.

\section{Manuscript received May 1986}

Revised manuscript received June 1986

\section{REFERENCES}

Allen, L. O. 1982. Palynology of the Palaeocene and Early Eocene of the London Basin. Unpub. PhD thesis, University of London.

Batten, D. J. 1981. Stratigraphic, palaeogeographic and evolutionary significance of Late Cretaceous and Early Tertiary Normapolles pollen. Rev. Palaeobot. Palynol., 35, 125-137.

Batten, D. J. 1982. Palynology of shales associated with the Kap Washington Group volcanics, central North Greenland. Gronlands geol. Unders., 108, 15-2.

Batten, D. J. 1984. Palynology, climate and the development of Late Cretaceous floral provinces in the Northern Hemisphere; a review. In Brenchley, P. J., Fossils and Climate, 127-164, Wiley, Chichester.

Batten, D. J., Brown, P. E., Dawes, P. R., Higgins, A. K., Koch, B. E., Parsons, I. \& Soper, N. J. 1981. Peralkaline volcanicity on the Eurasia Basin margin. Nature, 294, 150-152.

Boulter, M. C. 1984. Palaeobotanical evidence for landsurface temperature in the European Palaeogene. In Brenchley, P. J., Fossils and Climate, 35-48, Wiley, Chichester.

Boulter, M. C. \& Riddick, A. 1986. Analyses of palynodebris from the Palaeocene sediments of the Forties Field. Sedimentology, 33, 1-16. 
Brutman, N. J. 1973. Spore and pollen assemblages of Neogene deposits of North Sakhalin and their significance for stratigraphy [abstract]. In The Palynology of Cenophytic. Proceedings of III International Palynological Conference. Nauka, Moscow.

Collinson, M. E., Fowler, K. \& Boulter, M. C. 1981. Floristic changes indicate a cooling climate in the Eocene of southern England. Nature, 291, 315-317.

Costa, L. I. \& Downie, C. 1979. Cenozoic dinocyst stratigraphy of sites 403 to 406 (Rockall Plateau), IPOD, Leg 48. In Montadert, L. \& Roberts, D. G., Init. Repts. Deep Sea Drilling Project, 48, 513-530, Washington (U.S. Government Printing Office).

Croxton, C. A. 1980. Aquilapollenites from the Late Cretaceous - Paleocene (?) of central West Greenland. Rapp. Gronlands geol. Unders., 101, 5-27.

Curry, D., Adams, C. G., Boulter, M. C., Dilley, F. C., Eames, F. E., Funnell, B. K. \& Wells, M. K. 1978. A correlation of the Tertiary rocks of the British Isles. $S p$. Rep. Geol. Soc. Lond., $83 \mathrm{pp}$.

Evans, A. L., Fitch, F. J. \& Miller, J. A. 1973. Potassiumargon age determinations on some British Tertiary igneous rocks. J. geol. Soc. Lond., 129, 419-443.

Filippova, E. A. 1957. Stratigraphy of Mesozoic and Cenozoic periods of western Siberian lowland. [In Russian]. Stratigraphy of the Mesozoic and Cenozoic of the western Siberian Plain. State Union Western Siberian Petroleum Survey Trust, Moscow, 149 pp.

Frederiksen, N. O. \& Christopher, R. A. 1978. Taxonomy and biostratigraphy of Late Cretaceous and Paleogene triatriate pollen from South Carolina. Palynology, 2, 113-145.

Gronlie, G. 1979. Tertiary paleogeography of the NorwegianGreenland sea. Norsk Polarinstitutt Skrifter, 170, 49-61.

Hickey, L. J., West, R. M., Dawson, M. R. \& Choi, D. K. 1983. Arctic terrestrial biota: paleomagnetic evidence of age disparity with mid-northern latitudes during the Late Cretaceous and Early Tertiary. Science, 221, 1153-1156.

Koreneva, E. V., Zaklinskaya, E. D., Bratseva, G. M. \& Kartashova, G. G. 1976. Palynology studies of sites 336, 338, 345, 346 and 348, D.S.D.P. Leg 38. In Talwani, M. et al., Init. Repts. Deep Sea Drilling Project, 38, 1169-1194, Washington (U.S. Government Printing Office).

Lund, J. 1983. Biostratigraphy of interbasaltic coals from the Faeroe Islands. In Bott, M. H. P., Saxov, S., Talwani, M. \& Thiede, J. (Eds.), Structure and Development of the Greenland-Scotland ridge, 417-423, Plenum.

Manum, S. B. 1962. Studies in the Tertiary flora of Spitzbergen, with notes on Tertiary floras of Ellesmere Island, Greenland and Iceland. Norsk Polarinstitutt Skrifter, Oslo, 125, 127 pp.

Manum, S. B. 1976. Cenozoic biostratigraphy, physical stratigraphy and palaeooceanography in the NorwegianGreenland Sea, D.S.D.P. Leg 38 Palaeontological synthesis. In Talwani, M. et al., Init. Repts. of Deep Sea Drilling Project, 38, 1197-1212, Washington (U.S. Government Printing Office).

Martin, A. R. H. 1968. Aquilapollenites in the British Isles. Palaeontology, 11, 549-553.

Norris, G. 1986. Systematic and stratigraphic palynology of Eocene to Pliocene strata in the Imperial Nuktak C-22 well, Mackenzie Delta region, district of Mackenzie, N. W. T. Bull. Geol. Surv. Can., 340, 1-57.
Norris, G. \& Miall, A. D. 1984. Arctic biogeographic heterochroneity. Science, 224, 173-176.

Rouse, G. E. 1977. Paleogene palynomorph ranges in western and northern Canada. Amer. Ass. Strat. Pal. Contr. Ser. 5A, 48-61.

Salami, M. B. 1981. Late Cretaceous and Early Tertiary palynofloras from the southern Nigeria sedimentary basin. Unpub. PhD thesis, University of Cambridge, 311 pp., 43 pls.

Simpson, J. B. 1961. The Tertiary pollen-flora of Mull and Ardnamurchan. Trans. Roy. Soc. Edin., 64, 421-468.

Srivastava, S. K. 1970 . Pollen biostratigraphy and paleoecology of the Edmonton Formation (Maestrichtian), Alberta, Canada. Palaeogeography, Palaeoclimatol., Palaeoecol., 7, 221-276.

Srivastava, S. K. 1975. Maastrichtian microspore assemblages from the interbasaltic lignites of Mull, Scotland. Palaeontographica B, 150, 125-156.

Srivastava, S. K. 1981. Evolution of Upper Cretaceous phytogeoprovinces and their pollen flora. Rev. Palaeobot. Palynol., 35, 155-173.

Srivastava, S. K. 1983. Cretaceous phytogeoprovinces and paleogeography of the Indian plate based on palynological data. In Cretaceous of India, 141-157, Indian Association of Palynostratigraphers, Lucknow.

Staplin, F. L. (Ed.). 1976. Tertiary biostratigraphy, Mackenzie delta region, Canada. Bull. Can. Petrol. Geol., 24, 117-136.

Talwani, M. et al. 1976. Init. Repts. Deep Sea Drilling Project, 38, 1256 pp. Washington (U.S. Government Printing Office).

Throndsen \& Manum, S. B. In press.

Traverse, A. 1982. Response of world vegetation to Neogene tectonic and climatic events. Alcheringa, 6, 197-209.

Tschudy, R. H. \& Tschudy, B. D. 1984. Were there massive plant extinctions at the Cretaceous-Tertiary boundary? Abs. 6 Int. Pal. Conf., Calgary, 168.

Vinken, R. \& Meyer, K.-J. (Eds.) 1980. The northwest European Tertiary basin. Report 6. 143 pp., IGCP National Committee of FDR. Niedersachsiches Landesamt fur Bodenforschung, Hannover.

Wahrhaftig, C., Wolfe, J. A., Leopold, E. B. \& Lanphere, M. A. 1969. The coal-bearing group in the Nenana coal field, Alaska. Geol. Surv. Bulletin 1274-D, U.S. Government Printing Office, Washington.

Zhou, H. 1978. Early Tertiary spores and pollen grains from the coastal region of Bohai. [English abstract; Chinese text.] The Science Press, Peking. 177 pp.

Ziegler, P. A. 1982. Geological Atlas of Western Central Europe. Elsevier, Amsterdam. 131 pp. 